\title{
SOFTWARE FOR SEARCH AND MEASURING OF WDS CATALOG DOUBLE AND MULTIPLE STARS FROM DATABASE OF RESULTS OF CCD OBSERVATION
}

\author{
Yu.I. Protsyuk, N.V. Maigurova \\ Research Institute "Mykolaiv Astronomical Observatory", Mykolaiv, Ukraine \\ <yuri@mao.nikolaev.ua>, <nadija@mao.nikolaev.ua>
}

\begin{abstract}
Double and multiple star systems are the source of unique information for determining the parameters of star formation models and for testing stellar models evolution. Therefore observations and measuring of their mutual configuration parameters is still important.
\end{abstract}

Observations of double and multiple star systems at the Research Institute "Mykolaiv Astronomical Observatory" (RI MAO) were performed with different telescopes since 2013. In addition, we also have an observational database and proceeding results of the fields in open clusters vicinity, which were performed using the KT-50 telescope $(\mathrm{D}=500 \mathrm{~mm}, \mathrm{~F}=3000 \mathrm{~mm})$ in $2011-2020$. All astrometric processing was carried out by the Astrometrica software using UCAC4 or GAIA DR2 as reference catalogs. The catalogs of stars positions and proper motions in the vicinity of open clusters that contain more than 5.6 million stars were created as results of these observations. There are a lot of double and multiple stars in the fields with open clusters, which, moreover, could be the physical member of clusters. With this aim software for search and measuring of mutual configuration parameters of the double and multiple stars from the WDS was created. Our software uses previous reduction data from Astrometrica software and allows finding stars from double and multiple systems, which are presented in WDS catalog.

We determined separations and position angles for pairs of the found WDS systems and checked observational array over 71 nights of 2019. Data of 9679 CCD images were reduced and 34277 WDS pairs were found in 7232 of them. Total numbers of unique pairs are 1504 in 1091 systems with average number of pair observations near 23. The standard errors of measurements were $0.15^{\prime \prime}$ for separations and $0.5^{\circ}$ for position angles. The epoch difference between our observations and the last observation in the WDS database is in the range from 2 to 28 years. The comparison with the WDS data has shown that residual differences and their standard errors are $(-0.03 \pm 0.24)^{\prime \prime}$ in separations and $(-0.07 \pm 0.88)^{\circ}$ in position angles for close observation periods. The obtained data are of original observations that extend the observation period of stars from double and multiple systems and can be used to construct orbits and to determine the masses of components. The calculated parameters of mutual configuration of the found pairs and estimates of differences in magnitudes of the components will be sent to the WDS database.

Keywords: CCD observations, double and multiple stars, WDS catalog.
АНОТАЦІЯ. Подвійні та кратні зоряні системи є джерелом унікальної інформації для визначення пара-метрів моделей формування зірок та для тестування еволюції зоряних моделей. Тому спостереження та вимірювання їх взаємних параметрів конфігурації все ще $\epsilon$ важливим. Спостереження за подвійними та кратними зоряними системами в НДІ МАО проводяться 3 використанням різних телескопів з 2013 року. Крім того, ми також маємо базу даних спостережень та результатів обробки зоряних полів поблизу розсіяних скупчень, які проводились за допомогою телескопа КТ-50 (D = 500 мм, F = 3000 мм) у 2011-2020 pp. Вся астрометрична обробка проводилася за допомогою програмного забезпечення Astrometrica 3 використанням каталогів UCAC4 або GAIA DR2 в якості опорних. За результатами цих спостережень створено каталоги положень та власних рухів зірок в околицях розсіяних скупчень, що містять понад 5,6 млн зірок. В отриманих полях з розсіяними скупченнями є багато подвійних і кратних зірок, які, крім того, можуть бути фізичними членами розсіяних скупчень. Тому було створено програмне забезпечення для пошуку та вимірювання параметрів взаємної конфігурації подвійних та кратних систем з Вашингтонського каталогу подвійних зірок (WDS). Наше програмне забезпечення використовує попередні дані обробки від програмного забезпечення Astrometrica, знаходить там подвійні та кратні зірки, які представлені в каталозі WDS, та визначає їх взаємні відстані й позиційні кути. Перевірено масив спостережень за 71 ніч 2019 року.

Всього було оброблено дані 9679 ПЗ3-зображень, і в 7232 з них було знайдено 34277 пар подвійних зірок. Загальна кількість унікальних пар становить 1504 в 1091 системах із середньою кількістю спостережень пар 23. Стандартні похибки вимірювань становили 0.15" для відстаней та $0.5^{\circ}$ для позиційних кутів. Різниця епох між нашими спостереженнями та останнім спостереженням у базі даних знаходиться в діапазоні від 2 до 28 років. Порівняння 3 даними WDS показало, що залишкові різниці та їх стандартні похибки становили $(-0.03 \pm$ $0.24)$ " у відстанях та $(-0.07 \pm 0.88)^{\circ}$ в позиційних кутах для близьких періодів спостереження. Отримані дані $\epsilon$ оригінальними спостереженнями, які подовжують період спостереження подвійних та кратних зірок і можуть бути використані для побудови орбіт та визначення мас компонентів. Розраховані параметри взаємної конфігурації виявлених пар та оцінки різниць зоряних величин компонентів будуть передані в банк даних WDS.

Ключові слова: ПЗ3 спостереження, подвійні та кратні зірки, WDS каталог. 


\section{Introduction}

The observations of double and multiple systems were conducted at the RI MAO in 2013-2020 with the AMC and KT-50 telescopes (Bodryagin et al., 2014, 2015, 2017). Observational data were matched with the Washington Double Star Catalog (Mason et al. 2001) maintained by the US Naval Observatory. The WDS Catalog contains positions (J2000), discoverer designations, epochs, position angles, separations, magnitudes, spectral types, proper motions, and, when available, other information and notes for the components of 152,352 systems (till August 8, 2020). Not all the catalog objects have proven physical linkages between components. In many cases it is simply the result of close projection onto the celestial sphere of objects at different distances. As a rule, for stars in a gravitationally bound system the term "binary" used. Visual binary and multiple stars are mainly stars in the vicinity of the Sun with a very long orbital period. Due to the long period, the binary's orbit can be traced only by numerous observations over the course of tens of years. By this reason the orbits were determined only for several thousand stars: for example, the Sixth Catalog of Orbits of Visual Binary Stars as of July 27, 2017 (Hartkopf et al., 2001) included 2,739 orbits of 2,656 systems with sufficient accuracy to obtain estimates of the masses of the components.

Under the old processing scheme, our measurements were performed for each pair separately in manual mode, which made it impossible to process large volumes of observations. The REDUC software was used in this variant. At the same time, a combination of the ground based original observations with accurate astrometric catalogues is available due to the Strasbourg astronomical Data Centre. It allows to obtain new knowledge about nature of linkage between components of the investigated double and multiple systems (Maigurova, 2018), to search for vanishing stars (Villarroel et al., 2020) or probable invisible components inside of multiple stellar systems (Maigurova, 2019).

\section{Program of observations and software}

Simultaneously with the program of observations of double and multiple systems at the Mykolaiv Observatory, observations were conducted in frame of other programs. We have an observational database and proceeding results of the fields in open clusters vicinity, which were performed using the KT-50 telescope $(\mathrm{D}=500 \mathrm{~mm}$, $\mathrm{F}=3000 \mathrm{~mm}$ ) in 2011-2020 (Protsyuk et al., 2014, 2019). The observations were carried out in the zone of latitudes $\pm 30^{\circ}$ from the galactic plane. All astrometric processing was made with the Astrometrica software using UCAC4
(Zacharias et al., 2013) or GAIA DR2 (Gaia Collaboration, 2018) as reference catalogs. As a result of these observations we created the catalogs of stars positions and proper motions in the vicinity of open clusters that contain more than 5.6 million stars (Protsyuk et al., 2014). We supposed that these catalogs should include many double and multiple stars in open cluster fields, which, moreover, could be physical member of clusters.

Firstly, we created software for processing our CCD observations in manual mode (Fig. 1). This software works primarily with images with a small number of reference stars and has more stable results with more convenient manual processing than REDUC software.

Secondly, we created software to search for WDS pairs in the results of the previous processing performed by Astrometrica software.

The new AstroWDS program works in batch mode and uses the downloaded version of WDS catalog. The search is carried out in the WDS catalog sequentially for all stars from the Astrometrica's cat-file. The cross matching procedure is performing with the following configurable parameters: search radius of the main star for both coordinates is 3"; distance difference (WDS-Astrometrica) in the found pairs is no more than 5". Pairs with a distance of up to $2 "$ in the WDS catalog or in our processing are to be ignored due to FWHM of stars in our observations. Also, the angular difference (WDS-Astrometrica) in the found pairs is no more than 5 degrees.

The processing time is less than 1 second for one CAT file with few thousands of stars. The results are output in two files: detail one for all pairs and summary one with the most relevant information (Table 1), which can be sent to update the WDS catalog.

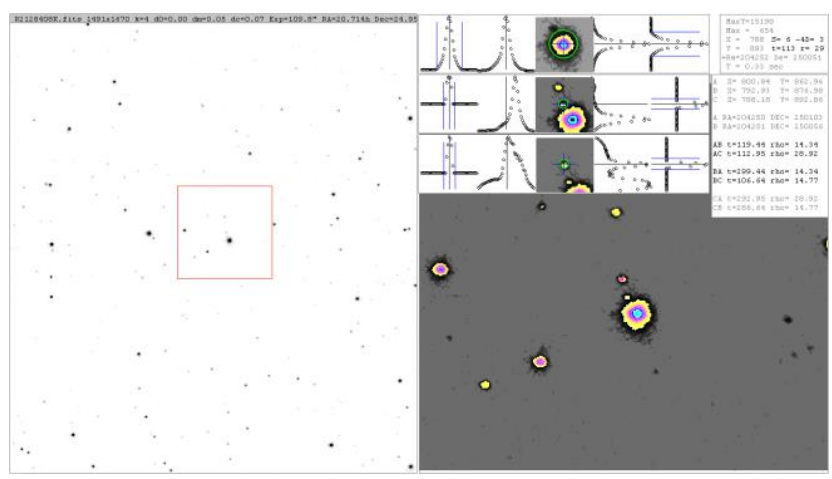

Figure 1: Software for processing CCD observations in manual mode.

Table 1: File format with summary information about the found pairs of stars.

\begin{tabular}{|c|c|c|c|c|c|c|c|c|c|c|c|c|}
\hline WDS & Comp & Obs & Date & & $\mathrm{pa}$ & sep & $\operatorname{mag} 1$ & $\operatorname{mag} 2$ & dmag & $\mathrm{pa}(\mathrm{O}-\mathrm{WDS})$ & $\operatorname{sep}(O-W D S)$ & $\mathrm{T}(\mathrm{WDS})$ \\
\hline $00013+6021$ & $\mathrm{AB}$ & 2019 & 09 & 21 & 89.35 & 57.45 & 8.07 & 8.47 & 0.40 & 0.35 & -0.25 & 2010 \\
\hline $00013+6021$ & $A B$ & 2019 & 09 & 21 & 89.35 & 57.49 & 8.93 & 9.86 & 0.93 & 0.35 & -0.21 & 2010 \\
\hline $00013+6021$ & $A B$ & 2019 & 09 & 21 & 89.51 & 57.26 & 8.42 & 8.74 & 0.32 & 0.51 & -0.44 & 2010 \\
\hline $00013+6021$ & $A B$ & 2019 & 10 & 18 & 89.26 & 57.44 & 8.34 & 9.32 & 0.98 & 0.26 & -0.26 & 2010 \\
\hline $00013+6021$ & $A B$ & 2019 & 10 & 18 & 89.31 & 57.39 & 8.54 & 9.48 & 0.94 & 0.31 & -0.31 & 2010 \\
\hline $00013+6021$ & $A B$ & 2019 & 11 & 09 & 89.09 & 57.36 & 8.88 & 9.90 & 1.02 & 0.09 & -0.34 & 2010 \\
\hline $00013+6021$ & $A B$ & 2019 & 11 & 09 & 89.44 & 57.51 & 8.57 & 9.68 & 1.11 & 0.44 & -0.19 & 2010 \\
\hline $00013+6021$ & $\mathrm{AC}$ & 2019 & 09 & 21 & 323.61 & 155.28 & 8.42 & 10.75 & 2.33 & -0.39 & 0.28 & 2007 \\
\hline $00013+6021$ & $\mathrm{AC}$ & 2019 & 09 & 21 & 323.77 & 155.29 & 8.07 & 10.43 & 2.36 & -0.23 & 0.29 & 2007 \\
\hline $00013+6021$ & $\mathrm{AC}$ & 2019 & 09 & 21 & 323.81 & 155.63 & 8.93 & 11.29 & 2.36 & -0.19 & 0.63 & 2007 \\
\hline $00013+6021$ & $\mathrm{AC}$ & 2019 & 10 & 18 & 323.72 & 155.32 & 8.34 & 10.75 & 2.41 & -0.28 & 0.32 & 2007 \\
\hline $00013+6021$ & $\mathrm{AD}$ & 2019 & 09 & 21 & 117.84 & 181.50 & 8.07 & 10.46 & 2.39 & -0.16 & 0.10 & 2016 \\
\hline
\end{tabular}



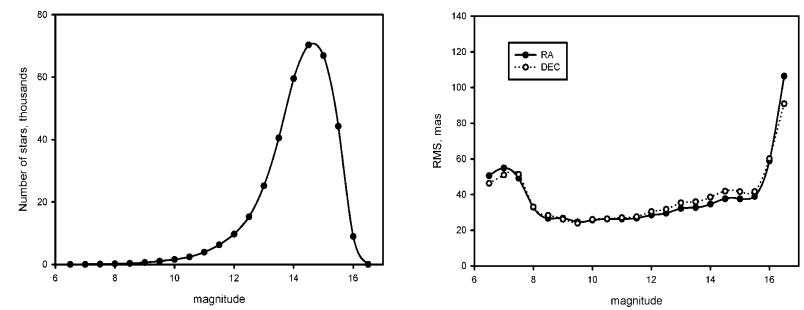

Figure 2: Distribution of stars from the MAO-2019: number of stars (left) and accuracy (right) vs. magnitude
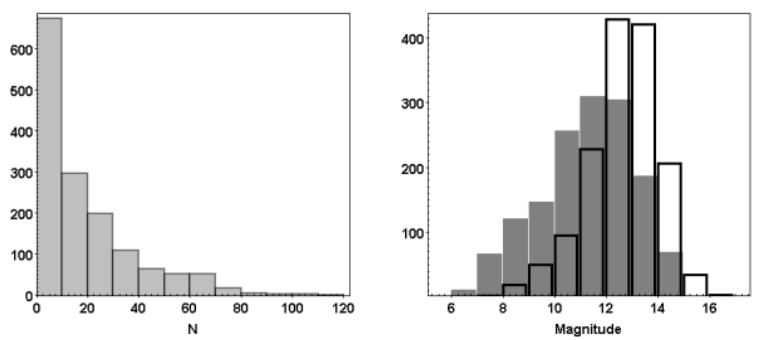

Figure 3: Number of observations of the found WDS pairs (left); distributions of these pairs by stellar magnitude (right): filled - first component, open - second one.

\section{Reductions and results}

In this article we use the KT-50 array of observations in 2019, which was processed by Astrometrica software. Observations were carried out in fields that include open clusters in the zone of latitudes $\pm 30^{\circ}$ from the galactic plane. In total, $9679 \mathrm{CCD}$ frames were obtained; 12 million objects were selected of CCD images. On the basis of these observation the MAO-2019 catalog of more than 357 thousand stars $(7 \div 16)^{\mathrm{m}}$, which have more than five observations was obtained (Fig. 2).

For our work we used these 9679 CAT files obtained in the process of creating the catalog to find the WDS pairs. As a result we selected 34277 WDS pairs from 7232 CAT-files. Total numbers of unique found pairs are 1504 in 1091 systems with average number of the observations of one pair near 23, a mean magnitude for the first component is $11.5 \mathrm{~m}$, for the second is $13 \mathrm{~m}$ (Fig. 3, 4). The standard errors of measurements were $0.15^{\prime \prime}$ in separations and $0.5^{\circ}$ in position angles (Fig. 5). The epoch difference between our observations and the last observations in the WDS is in the range from 2 to 28 years.

We compared the obtained values of the configuration parameters with data from WDS catalog and determined that residual differences and their standard errors were $(-0.03 \pm 0.24)^{\prime \prime}$ in separations and $(-0.07 \pm 0.88)^{\circ}$ in position angles for close observation periods (Fig. 6).

\section{Conclusions}

New software has been created for the search and subsequent measurement of the parameters of mutual configuration (angular distance between components and position angle) for double and multiple systems from the WDS catalog. This software uses positional files obtained in the process of performing astrometric reductions by Astrometrica software as input files.

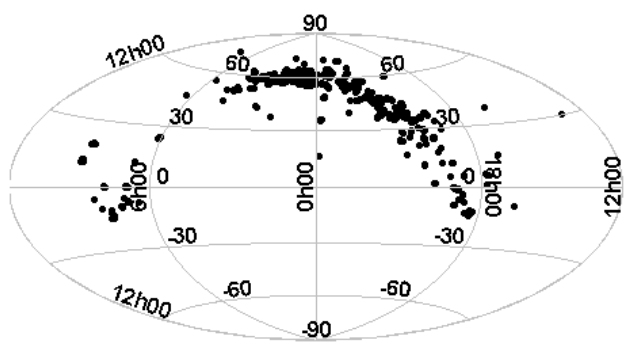

Figure 4: Celestial distribution of the found WDS systems in equatorial coordinates (Aitoff projection).
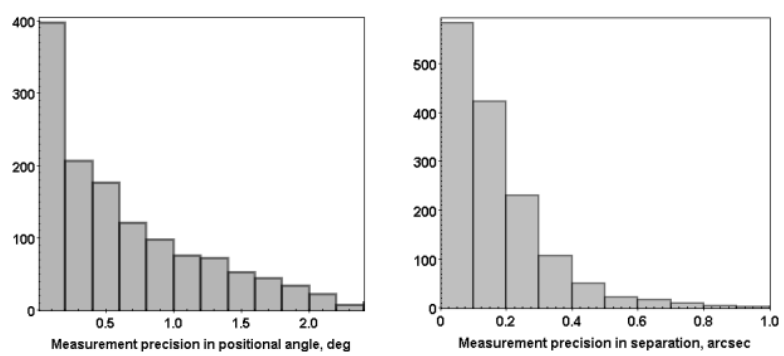

Figure 5: Measurement precision in positional angle (left) and separation (right) for the found WDS pairs.
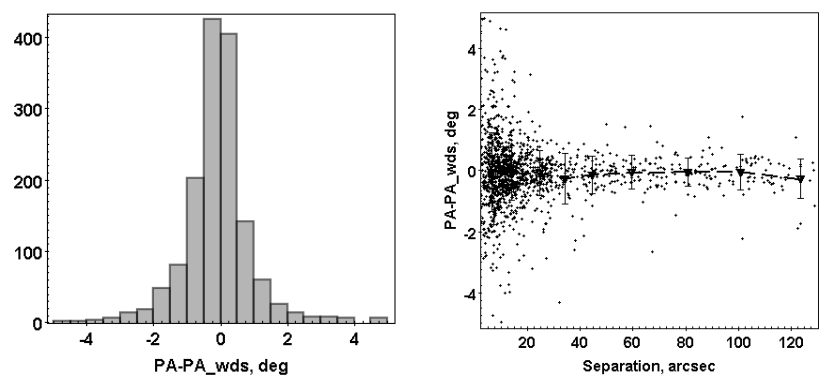

Figure 6: Histogram of positional angle differences between measured and WDS catalog values (left), relation of measurement accuracy of positional angle vs separation parameter (right).

The search and measurement of the parameters of the mutual configuration of the WDS catalog object were carried out on the array of KT-50 telescope observations of fields with open clusters in 2019. Totally we found 1504 pairs from 1091 systems of the WDS catalog for which mutual configuration parameters were measured. The average (median) number of observations of one pair is 15 times. For comparison, only 1019 systems with an average number of observations of about 5 were resulted according to the program of observations of double and multiple systems in 2014-2018. Comparison with the WDS data showed that the values of the differences in measurements of parameters of the mutual configuration and their standard errors are $(-0.03 \pm 0.24)$ " for the angular distance and $(-0.07 \pm 0.88)^{\circ}$ for the positional angle for close periods of observation.

New software will be included into the UkrVO resources (Vavilova et al., 2017, 2020) to help for anybody to find new objects, likely double and multiple star systems, inspecting the old observational data. 


\section{References}

Astromerica, [on-line resourse]. Available at: http://www.astrometrica.at

Bodryagin D. et al.: 2015, Odessa Astron. Publ., 28, 163. Bodryagin D.V. et al.: 2016, JDSO, 12, 320.

Bodryagin D.V. et al.: 2017, Sci. Innov., 13, 46.

Gaia Collaboration 2018, $A \& A$, 616, A1.

Hartkopf et al.: 2001, $A J, \mathbf{1 2 2}, 3472$.

Maigurova N.V. et al.: 2018, Odessa Astron. Publ., 31, 220.

Maigurova N.V. et al.: 2019, Odessa Astron. Publ., 32, 192.

Mason B.D. et al: 2001, Astron. J., 122, 3466.
Protsyuk Yu.I. et al.: 2014, KPCB, 30, N6, 296.

Protsyuk Yu.I. et al.: 2019, Odessa Astron. Publ., 32, 196. REDUC software, [on-line resourse]. Available at: http://www.astrosurf.com/hfosaf/reduc

Vavilova I.B. et al.: 2017, Proc. IAU Symp., 325, 361.

Vavilova I.B. et al.: 2020, in: Knowledge Discovery in Big Data from Astronomy and Earth Observation. DOI: 10.1016/B978-0-12-819154-5.00015-1, 57.

Villarroel B. et al.: 2020, Astron. J., 159, 2020.

Zacharias N. et al.: 2013, Astron. J., 145, 44. 